\title{
Nursery Schools: Characterization of heavy metal content in indoor dust
}

\author{
Fairus Muhamad-Darus ${ }^{1}$, Rabiatul Adawiyah Nasir ${ }^{2}$, \\ Siti Mariam Sumari ${ }^{1}$, Zitty Sarah Ismail ${ }^{1}$, Nur Aliah Omar ${ }^{1}$ \\ ${ }^{1}$ Faculty of Applied Sciences, \\ ${ }^{2}$ Faculty of Architecture, Planning \& Surveying, \\ Universiti Teknologi MARA, Malaysia \\ fairusmd@salam.uitm.edu.my
}

\begin{abstract}
Interior floor dust is found to be one of the major pathways of childhood exposure to indoor air pollutants. This study aims to carry out a general survey of heavy metals ( $\mathrm{Al}, \mathrm{Ba}, \mathrm{Cr}, \mathrm{Cu}, \mathrm{Fe}, \mathrm{Ni}$ and $\mathrm{Pb}$ ) contamination at selected nursery school buildings in Shah Alam, Selangor and to study their relationship with the surrounding environment. The samples were collected using a brush and a plastic dust pan, after which the samples were digested using the wet digestion method. The heavy metal concentration was determined by inductively coupled plasma - optical emission spectrometer (ICP$\mathrm{OES})$. The results show that the heavy metal concentrations at nursery school building were in the range 901.2 - 1510.0, 13.3 - 76.7, 12.0 - 22.6, 22.2 - 42.7, 1489.0 - 7919.0, 5.5 -14.4, 13.2 - 64.6, $93.3-220.4 \mathrm{mg} \mathrm{kg}^{-1}$ for $\mathrm{Al}, \mathrm{Ba}, \mathrm{Cr}, \mathrm{Cu}, \mathrm{Fe}, \mathrm{Ni}$ and $\mathrm{Pb}$ respectively. The heavy metal concentration in the investigated areas followed the order $\mathrm{Fe}>\mathrm{Al}>\mathrm{Zn}>\mathrm{Pb}>\mathrm{Ba}>\mathrm{Cu}>\mathrm{Cr}>$ Ni. Principal Component Analysis (PCA) was carried out to ascertain the possible contributing factors towards the metal concentrations and thereby determine which metals have a common origin. PCA analysis indicated that three factors indicated source of mixed origin including mobile vehicle, street dust and natural sources.
\end{abstract}

Keywords: Indoor dust, Heavy metal, Nursery school, Principal component analysis

eISSN 2514-751X @ 2017 The Authors. Published for AMER ABRA by e-International Publishing House, Ltd., UK. This is an open-access article under the CC BY-NC-ND license (http://creativecommons.org/licenses/by-ncnd/4.0). Peer-review under responsibility of AMER (Association of Malaysian Environment-Behaviour Researchers), ABRA (Association of Behavioural Researchers on Asians) and CE-Bs (Centre for EnvironmentBehaviour Studies), Faculty of Architecture, Planning \& Surveying, Universiti Teknologi MARA, Malaysia.

https://doi.org/10.21834/aje-bs.v2i5.223 


\subsection{Introduction}

Dust consist of solid matter or particulates in the form of fine powder (less $100 \mu \mathrm{m}$ ), lying on the ground or on the surface of objects or blown about by natural forces or mechanical forces (Adekola \& Dosumu, 2001). Indoor dust is present in the indoor environment as a composite of particulate matter derived from interior and exterior sources. Dust can enter an indoor environment in several ways such as infiltration from outdoor sources and internally from smoking, incense burning, buildings and furniture materials, consumer products and occupant activities (Al- Rahji and Seaward, 1996; Turner \& Simmonds, 2006). Indoor dust is a repository for environmental pollutants such as heavy metals that may accumulate indoors and is an important pathway of exposure to metal for humans. There is an increasing concern about heavy metals contamination in indoor environment since most people spend a great extent of their time indoors (Klepeis et al., 2001; Sharpe, 2004).

A number of studies have suggested that there is a possibility that metals in the indoor dust can accumulate in humans, either directly or indirectly by inhalation, ingestion as a result of hand-to mouth activity or via dermal contact absorption (Al-Rahji \& Seaward, 1996; Molhave et al., 2000). Young children, especially toddlers, can easily ingest soils or indoor dusts unintentionally since they spend most of their time indoors and much of this time is spent in contact with floors, engaging in mouthing of hands, toys and other objects or the consumption of food contaminated by hands (Mohd Tahir, 2007; Adekola \& Dosumu, 2001).

Heavy metals have an effect on biochemical mechanisms, especially because they can be bioaccumulated. An infant or child is extremely vulnerable to environmental interference because their organs are developing rapidly at early stage of development, making them more susceptible to functional damage or disorders (Yaaqub et al., 1991). These groups are also vulnerable to heavy metal poisoning since this is the period for maximal brain growth and differentiation (Tong \& Lam, 2000). Besides, the rate of absorption of heavy metals from the digestion system and the hemoglobin sensitivity to these metals in children is much higher than in adults (Tong \& Lam, 1998). It is now widely accepted that dust and soil are the predominant sources of heavy metals to which young children are exposed by mouthing of contaminated indoor dust (Chatterjee \& Banerjee, 1999; Tong \& Lam, 2000; Chattopadhyay et al., 2003).

Considerable attention has been paid to the study of metal pollution in city air, roadside dust and soils. However, there is a lack of concern on the presence of heavy metals in indoor dust in buildings such as in the nursery schools in Malaysia. Since there is limited data on dust contamination in the nursery schools, this study is important.

\subsection{Methodology}

\section{Site sampling}

Shah Alam is located in the center of the west coast of Peninsular Malaysia, at an altitude of 
$75 \mathrm{~m}$, being about $25 \mathrm{~km}$ from Kuala Lumpur, capital city of Malaysia. It is the capital city of Selangor state, the fasters growing state which has experienced rapid urbanization and industrialization in the last decades, with a present population estimated at 584,350. The nursery school buildings selected for this study lie mainly in the Shah Alam city. The schools sites were located at three different land use types; nursery 1 located inside residential area (Section 7), nursery 2 located close to commercial area (Section 9) and nursery 3 located close to industrial areas (Section 17). Table 1 shows the site description of selected nurseries.

Table 1: Site description of the nursey schools

\begin{tabular}{|c|c|c|c|c|c|}
\hline Site & $\begin{array}{l}\text { Landuse } \\
\text { Background }\end{array}$ & $\begin{array}{l}\text { Building } \\
\text { Type }\end{array}$ & $\begin{array}{l}\text { Number of } \\
\text { occupants }\end{array}$ & $\begin{array}{l}\text { Number of } \\
\text { windows }\end{array}$ & $\begin{array}{l}\text { Ventilation } \\
\text { condition }\end{array}$ \\
\hline $\begin{array}{l}\text { Nursery } 1 \\
\text { (Section } 7 \text { ) }\end{array}$ & $\begin{array}{l}\text { Residential area, } \\
800 \mathrm{~m} \text { from main } \\
\text { road with high }\end{array}$ & $\begin{array}{l}\text { Double } \\
\text { storey, } \\
\text { corner lot }\end{array}$ & $\begin{array}{c}22 \\
\text { traffic flow }\end{array}$ & 3 & $\begin{array}{l}\text { Fan, natural } \\
\text { ventilation all } \\
\text { the time }\end{array}$ \\
\hline $\begin{array}{l}\text { Nursery } 2 \\
\text { (Section 9) }\end{array}$ & $\begin{array}{l}\text { Closed to } \\
\text { commercial } \\
\text { zone area, } 10 \mathrm{~m} \\
\text { from main road }\end{array}$ & $\begin{array}{l}\text { Double } \\
\text { storey, } \\
\text { corner lot }\end{array}$ & vith high traffic & 6 & $\begin{array}{c}\text { Fan, natural } \\
\text { ventilation, air } \\
\text { conditioned in } \\
\text { main room }\end{array}$ \\
\hline $\begin{array}{l}\text { Nursery } 3 \\
\text { (Section 17) }\end{array}$ & $\begin{array}{l}\text { Closed to } \\
\text { industrial zone } \\
\text { area, } 10 \mathrm{~m} \text { from } \\
\text { main road with }\end{array}$ & $\begin{array}{l}\text { Single } \\
\text { story, } \\
\text { corner lot }\end{array}$ & $\begin{array}{c}28 \\
\text { high traffic }\end{array}$ & 6 & $\begin{array}{c}\text { Fan, natural } \\
\text { ventilation, air } \\
\text { conditioned } \\
\text { in main room }\end{array}$ \\
\hline
\end{tabular}

\section{Sample collection}

Indoor dust was collected from three nurseries representing three different background sites of different land use types within Shah Alam city area during March-April 2010. Using a clean plastic brush and pan, dust was collected inside the nursery building by sweeping the classroom floor which was most accessible to the children. The indoor dust was then transferred into a reseal able plastic bag, brought to the laboratory and placed in a desiccator for $24 \mathrm{~h}$, sieved through a $100-\mathrm{m}$ screen, and finally oven dried at $105^{\circ} \mathrm{C}$ for $24 \mathrm{~h}$.

\section{Sample and data analysis}

Immediately after drying, about $0.3-0.5 \mathrm{~g}$ of the fine portion of the dust was then digested by using $3 \mathrm{~mL}$ of mixture solution ( $\mathrm{HCl}-\mathrm{HNO}-\mathrm{H} \mathrm{O}$ ) in a ratio of $2: 2: 2$ to form aqua regia acid at $95^{\circ} \mathrm{C}$ for at least one hour until white fumes appeared. The extract was cooled and was filtered through Whatman No. 42 filter papers. The filtrate was then made up to a volume of $50 \mathrm{~mL}$ in the volumetric flask with distilled water and was analyzed for metal content by using Inductively Coupled Plasma-Optical Emission Spectroscopy (ICP-OES) to determine the 
concentration of $\mathrm{Al}, \mathrm{Ba}, \mathrm{Cr}, \mathrm{Cu}, \mathrm{Fe}, \mathrm{Ni}, \mathrm{Pb}$ and $\mathrm{Zn}$ heavy metals. The blank experiment was carried out by repeating the procedure for sample preparation without the sample. The composition of the blank solution was compared with the sample solution to identify the elemental composition of heavy metals in the dusts.

Data were analyzed for analysis of variance (ANOVA), correlation functions and factors analysis using statistical functions in Microsoft Excel and Statistical Packages for the Social Sciences (SPSS), included.

\subsection{Results and Discussions}

\section{Heavy metals concentration}

The mean concentrations of heavy metals in the indoor dust samples are summarized in Table 2. The concentration of heavy metals in nursery schools building were depends upon dustiness and ventilation of the building. The highest concentration heavy metal obtained was $\mathrm{Fe}$ with the mean concentration $4225.33 \mathrm{mg} / \mathrm{kg}$ and followed by Al with the mean concentration of $1229.58 \mathrm{mg} / \mathrm{kg}$. Both Al and Fe are abundant elements in the Earth's crust (AlKhashman, 2004; Hunt et al., 2008). These elements have been produced by alteraction (friction) and distributed or transported via wind blow and can be associated with soil or street dust. The result indicated that soil or street dust play an important role in the concentration build up in indoor dust in the nursery school building.

Table 2: Descriptive statistics of indoor dust heavy metal concentration $(\mathrm{mg} / \mathrm{kg})(N=9)$

\begin{tabular}{lrrrrrrrc}
\hline & \multicolumn{1}{c}{ Al } & Ba & \multicolumn{1}{c}{ Cr } & \multicolumn{1}{c}{ Cu } & Fe & Ni & Pb & Zn \\
\hline Mean & 1229.58 & 30.90 & 16.88 & 30.19 & 4225.33 & 9.00 & 31.24 & 148.71 \\
SD & 214.77 & 18.91 & 3.61 & 6.25 & 2282.01 & 3.24 & 17.49 & 44.19 \\
Min & 901.20 & 13.30 & 12.00 & 22.20 & 1489.00 & 5.50 & 13.20 & 93.30 \\
Median & 1149.00 & 27.40 & 16.20 & 29.50 & 3931.00 & 9.10 & 25.50 & 159.00 \\
Max & 1510.00 & 76.70 & 22.60 & 42.70 & 7919.00 & 14.40 & 64.60 & 220.40 \\
\hline
\end{tabular}

$\mathrm{SD}$ - Standard deviation

Heavy metals find their way into indoor building or in this case children's nurseries either as airborne dust or through items used or activities carried out within the nursery by occupant's activities. In addition, activities carried out at surrounding area or in the vicinity also contribute to indoor dust and may direct or indirectly characterize the type of metals found indoor. The locations of all nursery schools were close to the main road with high traffic density and therefore it is expected to contain high lead $(\mathrm{Pb})(31.24 \mathrm{mg} / \mathrm{kg})$ in indoor dust related to the automobile emission (Chattopadhyay et al., 2003). $\mathrm{Pb}$ is a universal pollutant in an urban environment due to automobile emission (Al Rahji and Seaward, 1996), and despite the gradual shift from leaded to unleaded petrol as fuel for automobile, it still remains as a 
major pollutant for some urban areas including Shah Alam city.

Other metals such as $\mathrm{Zn}, \mathrm{Cu}, \mathrm{Cr}$, $\mathrm{Ni}$ and $\mathrm{Ba}$ were also related to automobile emission. As cited throughout the literature, the source of $\mathrm{Zn}$ in dust may have its origin from automotive sources i.e. wear and tear of vulcanized rubber tyres, lubricating oils and corrosion of galvanized vehicular parts (Li et al. 2001; Al- Khashman, 2004; Adachi and Tainosho, 2004). The source of $\mathrm{Cu}, \mathrm{Cr}$ and $\mathrm{Ni}$ in dust is believed to be from car components, tyre abrasion, lubricants corrosion of cars, engine wear, thrust bearing, brushing, bearing metals and brake dust respectively (Al Rahjiand Seaward, 1996;Al-Khashman, 2004;2007).

Although heavy metals in dust could be derived from indoor and outdoor sources, the result of this study indicated that major influence was from outdoor sources. The possible routes of heavy metals entering the schools building were through the open windows for cooling and ventilation (Komarnicki, 2005). While recognizing the fact that, the movement of occupant's in and out from building also contributed the heavy metals concentration in the building, its contribution was less obvious from the contribution from ambient sources.

\section{Correlation coefficient analysis}

Pearson's correlation coefficient can be used to measure the degree of correlation between logarithms of the heavy metals data. The correlations of heavy metals in indoor dusts of the nursery schools building are depicted in Table 3. All the metal pairs showed negative relations except for Al-Ni, Al-Zn, Cu-Fe and Ni-Zn pairs which were significant at $95 \%$ and/or higher confidence level. Al, Ni and $\mathrm{Zn}$ significantly correlated with each other (0.792 and 0.749$)$ at $95 \%$ or higher confidence level, which may indicate a common sources origin, such as automobile emission.

\section{Factor analysis}

The principal component matrix analysis is given in Table 4. Principal Component Analysis (PCA) was carried out to ascertain the possible contributing factors towards the metal concentrations and thereby determine which metals have a commonorigin.

Table 3: Correlation matrix for the heavy metal concentrations

\begin{tabular}{|c|c|c|c|c|c|c|c|c|}
\hline & $\mathrm{Al}$ & $\mathrm{Ba}$ & $\mathrm{Cr}$ & $\mathrm{Cu}$ & $\mathrm{Fe}$ & $\mathrm{Ni}$ & $\mathrm{Pb}$ & $\mathrm{Zn}$ \\
\hline Al & 1.000 & 0.519 & -0.323 & -0.215 & 0.282 & $0.792^{*}$ & -0.075 & $-0.749^{*}$ \\
\hline $\begin{array}{l}\mathrm{Ba} \\
\mathrm{Cr} \\
\mathrm{Cu} \\
\mathrm{Fe} \\
\mathrm{Ni} \\
\mathrm{Pb} \\
\mathrm{Zn}\end{array}$ & & 1.000 & $\begin{array}{r}-0.242 \\
1.000\end{array}$ & $\begin{array}{r}0.160 \\
-0.127 \\
1.000\end{array}$ & $\begin{array}{r}-0.145 \\
0.364 \\
-0.730^{*} \\
1.000\end{array}$ & $\begin{array}{r}0.527 \\
-0.205 \\
0.008 \\
0.018 \\
1.000\end{array}$ & $\begin{array}{r}0.591 \\
0.323 \\
0.311 \\
-0.258 \\
0.386 \\
1.000\end{array}$ & $\begin{array}{c}-0.415 \\
0.292 \\
0.375 \\
-0.238 \\
-0.871^{\text {** }} \\
-0.227 \\
1.000\end{array}$ \\
\hline
\end{tabular}




\begin{tabular}{cccc} 
Table 4: Factor loadings and communalities of heavy metals \\
\hline Item / Component & Factor-1 & Factor-2 & Factor-3 \\
Eiqenvalue & 3.21 & 2.19 & 1.43 \\
Explained yariances (\%) & 40.2 & 27.3 & 17.8 \\
\hline $\mathrm{Al}$ & 0.876 & -0.226 & -0.200 \\
$\mathrm{Ba}$ & 0.700 & 0.428 & 0.168 \\
$\mathrm{Cr}$ & -0.332 & -0.194 & 0.864 \\
$\mathrm{Cu}$ & -0.165 & 0.874 & -0.112 \\
$\mathrm{Fe}$ & 0.133 & -0.870 & 0.313 \\
$\mathrm{Ni}$ & 0.928 & 0.102 & 0.062 \\
$\mathrm{~Pb}$ & 0.326 & 0.585 & 0.706 \\
$\mathrm{Zn}$ & -0.913 & 0.209 & 0.003 \\
\hline
\end{tabular}

Three factors that have eigenvalues $>1$ were extracted. The total variance explained by these three factors was $85.3 \%$. The first factor explains the greatest amount of variance $(40.2 \%)$ which is predominantly loaded by $\mathrm{Ni}, \mathrm{Zn}, \mathrm{Al}$ and $\mathrm{Ba}$. This factor may indicate a source of mixed origin including air-borne emissions originated from mobile vehicle, street dust and soil dust. The second factor (27.3\%) is characterized by high loading of $\mathrm{Cu}$ and $\mathrm{Fe}$ but moderately by $\mathrm{Pb}$, which is characteristically identified with vehicles and street dust. $\mathrm{Pb}$ also has been distributed between the second and third factor with moderate load value. The third factor is indicative of automobile emission sources.

\subsection{Conclusions}

The chemical analysis of indoor dust sample in nursery schools building in this study showed the distribution and concentration of heavy metals within the area of study. The results show the concentration of heavy metals at three nursery schools building were in range of 901.2-1510.0, 13.3-76.7, $12.0-22.6,22.2$ - 42.7, $1489.0-7919.0,5.5-14.4,13.2$ - 64.6, 93.3 - $220.4 \mathrm{mg} \mathrm{kg}^{-1}$ for $\mathrm{Al}, \mathrm{Ba}, \mathrm{Cr}, \mathrm{Cu}, \mathrm{Fe}, \mathrm{Ni}$ and $\mathrm{Pb}$ respectively. The result of heavy metal concentration in investigated areas were in order $\mathrm{Fe}>\mathrm{Al}>\mathrm{Zn}>\mathrm{Pb}>\mathrm{Ba}>\mathrm{Cu}>\mathrm{Cr}>\mathrm{Ni}$. Data analyses indicate that automobile emission is the major source of these heavy metals in indoor dust. The concentrations of heavy metals in nursery schools building were influenced by the dustiness and ventilation of the building.

Since the health effects caused by contaminated dust may have long-term effects on the children, action should be taken to avoid or minimize the potential risks of this silent epidemic. Therefore a good housekeeping practice such as frequent wet mopping and vacuuming and good maintenance of the ventilation system by closing those windows that are facing major roads should be taken into consideration in order to reduce children exposure to contaminated dust by heavy metals in nursery school buildings. 


\section{Acknowledgement}

The authors would like to thank the owners of the nursery schools for giving the opportunity and cooperation to successfully perform this study.

\section{References}

Adachi, K. \& Tainosho, Y. (2004). Characterization of heavy metal particles embedded in tire dust. Environment International, 30: 1009-1017.

Adekola, F.A. \& Dosumu, O.O. (2001). Heavy metal determination in household dust from llorin City, Nigeria. J. Nigeria Society for Experimental Biology, 3(1):217-221.

Al-Khashman, O.A. (2004). Heavy metal distribution in dust, street dust and soils from the work place in Karak Industrial Estate, Jordan. Atmospheric Environment, 38: 6803-6812.

Al-Khashman, O. A. (2007). The investigation of metal concentrations in street dust samples in Aqaba city, Jordan. Environmental Geochemistry and Health, 29: 197- 207.

Al-Rahji, M.A. \& Seaward, M.R.D. (1996). Metal level in indoor and outdoor dust in Riyadh, Saudi Arabia. Environmental International, 22(3): 315-324.

Chatterjee, A. \& Banerjee, R.N. (1999). Determination of lead and other metals in a residential area of greater Calcutta. The Science of the Total Environment, 227: 175- 185.

Chattopadhyay, G., Lin, K.C. \& Feitz, A.J. (2003). Household dust metal level in Syney metropolitan area. Environmental Research, 93: 301-307.

Hunt, A., Johnson, D.L., Brooks, J. \& Griffith, A.D. (2008). Risk remaining from the particle contaminants after vacuum cleaning of hard floor surface. Enviro Geochem Health, 30: 597-611.

Komarnicki, G.J.K. (2005). Lead and cadmium in indoor air and the urban environment. Environmental Pollution, 136: 47-61.

Klepeis, N.E., Nelson, W.C., Ott, W.R., Robinson, J.P., Tsang, A.M., Switzer, P., Behar, J.V., Hern, S.C. \& Engelmann, W.H. (2001). The National Human Activity Pattern Survey (NHAPS): A resource for assessing exposure to environmental pollutants. J. Exposure Analysis and Environmental Epidemiology, 11: 231-252.

Li, X., Poon, C.S. \& Liu, P.S. (2001). Heavy metal contamination of urban soils and street dusts in Hong Kong. Applied Geochemistry, 16: 1361-1368.

Mohd Tahir, N., Chee, P.S. \& Jaafar, M. (2007). Determination of heavy metals content in soil and indoor dusts from nurseries in Dungun, Terenganu. The Malaysia Journal of Analytical Sciences, 11:280-286.

Molhave, L., Schneider, T., Kjaergaard, S.K., Larsen, L., Norn, S. \& Jorgensen, O. (2000). House dust in sevem Danish offices. Atmospheric Environment, 34: 4767-4779.

Sharpe, M. (2004). Safe as houses? Indoor air pollution and health. J. Environmental Monitoring, 6: 46-49. 
Muhamad-Darus, F., et.al. / Asian Journal of Environmen-Behaviour Studies, ajE-Bs, 2(5) Oct / Dec 2017 (p.63-70)

Tong, S.T.Y. \& Lam, K.C. (1998). A nursery schools and kindergardens safe for our kids? The Hong Kong study. Science of the Total Environment, 216: 217-225.

Tong, S.T.Y. \& Lam, K.C. (2000). Home sweet home? A case study of household dust contamination in Hong Kong. Science of the Total Environment, 256: 115-123.

Turner, A. \& Simmonds, L. (2006). Elemental concentration and metal bioaccessibility in UK household dust. Science of the Total Environment, 371: 74-81.

Yaaqub, R.R., Davies, T.D., Jickells, T.D. \& Miller, J.M. (1991). Trace elements in daily collected aerosols at a site in south-eastern England. Atmospheric Environment, 25: 985-996. 